\title{
PENGARUH KEBIJAKAN KAWASAN PERDAGANGAN BEBAS TERHADAP PERKEMBANGAN DAERAH DI KOTA BATAM PERIODE TAHUN 2010-2014
}

\author{
Nur Kholidah Berlian ${ }^{1}$, Linayati Lestari ${ }^{2}$, Rahmayandi Mulda ${ }^{3}$ \\ ${ }^{1}$ Prodi Ilmu Pemerintahan, Fakultas Ilmu Sosial dan Ilmu Politik, Universitas Riau Kepulauan, Indonesia \\ bianlian8@yahoo.com \\ ${ }^{2}$ Prodi Ilmu Pemerintahan, Fakultas Ilmu Sosial dan Ilmu Politik, Universitas Riau Kepulauan, Indonesia \\ linayatilestari@yahoo.com \\ ${ }^{3}$ Prodi Ilmu Pemerintahan, Fakultas Ilmu Sosial dan Ilmu Politik, Universitas Riau Kepulauan, Indonesia \\ ramayandim@gmail.com
}

\begin{abstract}
Abstrak
Penelitian ini mengkaji dan menjawab permasalahan mengenai pengaruh kebijakan kawasan perdagangan bebas terhadap perkembangan daerah di kota Batam periode tahun 2010-2014. Tujuan dan manfaat dari penelitian yaitu, mengetahui pengaruh kebijakan kawasan perdagangan bebas terhadap perkembangan daerah di kota Batam periode tahun 2010-2014 untuk pengembangan ilmu pengetahuan pada kajian analisis penerapan suatu kebijakan. Metode penelitian ini yaitu menggunakan metode campuran untuk menghasilkan data yang bersifat statistik dan deskriptif. pengumpulan data diperoleh dari hasil observasi, angket, dokumentasi dan wawancara serta teknik analisis data yang digunakan yaitu metode skala likert. Hasil penelitian ini menunjukkan bahwa terdapat pengaruh kebijakan kawasan perdagangan bebas terhadap perkembangan daerah di kota Batam periode tahun 2010-2014 yang membawa kearah perkembangan yang lebih baik.

Kata Kunci : pengaruh, kebijakan, kawasan perdagangan bebas, perkembangan daerah.
\end{abstract}

\begin{abstract}
This study examines and answers issues concerning the influence of free trade area policy on regional development in Batam period 2010-2014 period. Objectives and benefits of research that is, to know the influence of free trade area policy on regional development in the city of Batam period 2010-2014 for the development of science on analysis analysis of the implementation of a policy. The method of this research is using mixed method to produce data that is statistic and descriptive. collecting data obtained from the observation, questionnaires, documentation and interviews and data analysis techniques used Likert-scale method. The results of this study indicate that there is influence of free trade area policy on regional development in the city of Batam period 2010-2014 which leads to better development.

Keywords: influence, policy, free trade area,regional development.
\end{abstract}




\section{PENDAHULUAN}

Pengembangan daerah merupakan strategi memanfaatkan dan mengkombinasikan faktor internal dan eksternal, ada sebagai potensi dan peluang yang dapat dimanfaatkan untuk meningkatkan produksi daerah akan barang dan jasa yang merupakan fungsi dari kebutuhan baik secara internal maupun eksternal daerah. Para perencana dan politisi negara-negara baru di masa pasca-perang melihat industrialisasi dan pembangunan sebagai hal yang sejalan dan sangat diperlukan.

Industrialisasi dipandang sebagai sarana untuk melepaskan diri dari ketergantungan kolonial melalui ekspor produk-produk pertanian dan bahan baku. Ini akan mengatasi kendala neraca pembayaran dengan diversifikasi ekspor dan setidaknya memberikan fondasi bagi ekonomi domestik, yang modern, dan mandiri. Memang sebuah karakteristik strategi industrialisasi berorientasi ekspor yang sering menjadi taktik sentral telah menjadi zona pemrosesan ekspor Export processing zone atau zona perdagangan bebas free trade zone (United Nations and Korea Maritime Institute, 2005).

Free Trade Zone sebagai salah satu bentuk dari zona ekonomi pada umumnya memiliki pengertian yang cukup beragam. Hal ini diduga sebagai akibat adanya perbedaan dalam sudut pandang atau bobot tinjauan para ahli itu sendiri tentang konsep free trade zone tersebut. Perdagangan bebas adalah konsep teoritis yang mengandaikan berlakunya sistem perdagangan internasional yang dibebaskan dari hambatan yang disebabkan oleh ketentuan pemerintah suatu negara, baik yang disebabkan oleh pengenaan tariff maupun nir-tarif.

Free Trade Zone secara luas masih dianggap sebagai salah satu kebijakan ekonomi yang sangat diandalkan bagi negara-negara berkembang untuk mempromosikan pembangunan ekonomi dan menarik perusahaan asing. Dan kemungkinan keberhasilan penerapan sebuah Free Trade Zone lebih tinggi di negara-negara berkembang daripada negara kurang berkembang.Pada tanggal 1 April 2009 Batam yang telah resmi menjadi kawasan free trade zone melalui pelimpahan kewenangan penerbitan perizinanPermendagNo.12/MDAG/PER/3/2000.

Menurut Drijen Perdagangan luar negeri Depdag Diah Maulida pelimpahan kewenangan penerbitan perizinan di bidang perdagangan sesuai Permendag No. 12/MDAG/PER/3/2000 sesuai amanat UU untuk menarik investor asing.Kota Batam dapat memainkan peranannya sebagai extension industri bagi Singapura. Industri yang akan 
dikembangkan haruslah bersifat water saving terkait sustainability sumber air baku di Kota Batam. Sedangkan bagi international market, dapat diposisikan sebagai front liner investasi dan perdagangan global dengan Singapura sebagai jembatannya, untuk jangka pendek dan menengah. Untuk jangka panjang, dengan segenap potensi yang dimilikinya, harus mampu secara mandiri memposisikan diri sebagai kawasan investasi yang menjadi pilihan bagi investor-investor dunia.

Kota Batam adalah sebuah kota yang dibangun untuk mendorong pertumbuhan ekonomi di Indonesia bagian barat. Kota Batam dibuka sebagai kota industri dengan mendatangkan investor baik dari dalam maupun luar negeri. Dengan memberikan banyak keistimewaan pada Kota Batam diharapkan dapat terus mendorong masuknya investasi ke Kota Batam. Perekonomian Kota Batam pada tahun 2014 melaju dibandingkan pertumbuhan tahun-tahun sebelumnya. Laju pertumbuhan produk domestik regional bruto kota Batam tahun 2014 mencapai 7,99\%; sedangkan tahun 2013 sebesar 7,00 \%; tahun 2011 sebesar 7,83 $\%$; dan 2012 sebesar 7,40\%.

Selama periode 2010-2014, struktur perekonomian masyarakat kota Batam di lihat dari produk domestik regional bruto perkapita atas dasar harga berlaku mengalami peningkatan dengan jumlah nilai yang sedikit. Sedangkan di lihat dari produk domestik regional bruto perkapita atas dasar harga konstan mengalami perubahan dengan angka yang lebih banyak di banding dengan produk domestik regional bruto perkapita atas dasar harga berlaku. Selain itu Kelompok kategori usaha sekunder tetap mendominasi selama kurun waktu lima tahun terakhir sedangkan lompok kategori usaha yang dominan kedua adalah kelompok kategori usaha tersier dan kelompok kategori usaha primer menempati posisi ketiga.

\section{KAJIAN PUSTAKA}

Surakhmad menyatakan bahwa pengaruh adalah kekuatan yang muncul dari suatu benda atau orang dan juga gejala yang dapat memberikan perubahan terhadap apa-apa yang ada di sekelilingnya (Surakhmad, 1982).

Menurut Robert Dahl. (dalam Fairholm, 2009) Pengaruh adalah X mempunyai pengaruh atas $\mathrm{Y}$ sejauh ia dapat menyebabkan $\mathrm{Y}$ untuk berbuat sesuatu yang sebenarnya tidak akan Y lakukan, dalam hal tersebut suatu hubungan timbal balik atau hubungan sebab 
akibat anatara apa yang mempengaruhi dan apa yang di pengaruhi menjadi faktor dalam melihat adanya suatu pengaruh.

Teori Pertumbuhan Neoklasik, dasar teori ini terletak pada kompenen produksi yang sangat berpengaruh terhadap perkembangan daerah yaitu modal, tenaga kerja dan teknologi. Semakin besar kemampuan daerah dalam penyediaan 3 faktor tersebut, semakin cepat pertumbuhan daerah (Richardson, 1973).

\section{METODOLOGI PENELITIAN}

\section{Jenis Penelitian Dan Lokasi}

Jenis Penelitian ini adalah jenis penelitian yang menggunakan metode campuran (Mixed Methodology). Mixed Methods Research adalah adalah suatu disain penelitian yang didasari asumsi seperti halnya metode inkuiri (Creswell dan Plano Clark, 2008). Subjek dari penelitian ini yaitu kantor BP Batam dengan terfokus pada pengaruh kebijakan kawasan perdagangan bebas terhadap perkembangan daerah di kota Batam pada tahun 2010-2014.

\section{Teknik Pengumpulan Data}

Observasi adalah pengamatan dan pencatatan dengan sistematis dan sengaja sebagai pengamatan dan pengamatan terhadap obyek yang diselidiki dalam arti luas observasi sebenarnya tidak hanya terbatas pada pengamatan yang dilakukan dengan mata kepala saja, melainkan juga semua jenis pengamatan yang dilakukan baik secara langsung maupun tidak langsung.

Wawancara adalah teknik pengumpulan data dengan tanya jawab sepihak dengan yang dikerjakan secara sistematis berdasarkan tujuan penyelidikan pada umumnya dua atau lebih orang yang hadir dalam proses tanya jawab itu secara fisik masing masing pihak dapat menggunakan saluran komunikasi secara wajar dan lancer.

Angket atau kuesioner merupakan suatu teknik pengumpulan data secara tidak langsung.Instrumen atau alat pengumpulan datanya juga disebut angket berisi sejumlah pertanyaan-pertanyaan yang harus dijawab atau direspon oleh responden.

Kata dokumen berasal dari bahasa latin yaitu docere, yang berati mengajar. Terdapat 2 (dua) Pengertian dari kata "dokumen" yaitu pertama, berarti sumber tertulis bagi informasi 
sejarah sebagai kebalikan daripada kesaksian lisan, artefak, peninggalan-peninggalan terlukis, dan petilasan-petilasan arkeologis.

\section{Populasi Dan Sampel}

Dalam menentukan berapa besar sampel yang diperlukan dalam sebuah survei. Salah satu cara penentuan dapat menggunakan tabel yang disusun oleh Krejcie dan Morgan sebagaimana terdapat dalam Determining sample size for research activities (Robert V. Krejcie, 1970).

Tabel 1 Tabel Krejcie dan Morgan

\begin{tabular}{|c|c|c|c|}
\hline N & $S$ & N & $S$ \\
\hline 10 & 10 & 100 & $E 0$ \\
\hline 15 & 14 & 110 & $B 6$ \\
\hline 20 & 19 & 120 & 92 \\
\hline 25 & 24 & 130 & 97 \\
\hline 30 & 20 & 140 & 103 \\
\hline 35 & 32 & 150 & 103 \\
\hline 40 & 36 & 160 & 113 \\
\hline 45 & 40 & 100 & 113 \\
\hline 50 & 44 & 190 & 123 \\
\hline 55 & 49 & 200 & 127 \\
\hline 60 & 52 & 210 & 132 \\
\hline 65 & 56 & 220 & 136 \\
\hline 70 & 59 & 230 & 140 \\
\hline 75 & 63 & 240 & 144 \\
\hline 60 & 66 & 250 & 143 \\
\hline 65 & 70 & 250 & 152 \\
\hline 90 & 73 & 270 & 155 \\
\hline 55 & 76 & 270 & 153 \\
\hline
\end{tabular}

Sumber :Robert V. Krejcie, Determining Sample Size For Research Activities 1970.

Populasi dalam penelitian ini adalah keseluruhan obyek yang menjadi sasaran penelitian yaitu 65 (enam puluh lima) petugas BP Kota Batam serta masyarakat dan industry yang terlibat dalam kebijakan kawasan perdagangan bebas di Kota sehingga dapat disimpulkan bahwa sampel yang digunakan dalam penelitian ini adalah sebanyak 56 sample.

\section{Teknik Analisis Data}

Dalam penelitian ini teknik analisis data yang digunakan adalah metode skala likert, skala likert adalah sebuah tipe skala psikometri yang menggunakan angket dan menggunakan skala yang lebih luas dalam penelitian survei. Metode rating yang dijumlahkan (summated rating) popular juga dengan nama penskalaan model Likert. Metode Likert merupakan metode penskalaan pernyataan sikap yang menggunakan distribusi respons sebagai dasar penentuan nilai skalanya (Azwar, 1995). 
Tabel 2 Kategori dalam Skala Likert

\begin{tabular}{|ll|ll|}
\hline \multicolumn{2}{|l|}{ Pernyataan Positif (+) } & \multicolumn{2}{|c|}{ Pernyataan Negatif (-) } \\
\hline 1. & sangat tidak setuju & 1. & sangat setuju \\
2. & tidak setuju & 2. & setuju \\
3. & ragu-ragu & 3. & ragu-ragu \\
4. & setuju & 4. & tidak setuju \\
5. & sangat setuju & 5. & sangat tidak setuju \\
\hline
\end{tabular}

Sumber : Saifuddin Azwar, Sikap Manusia: Teori dan Pengukurannya

\section{ANALISIS DAN PEMBAHASAN}

Kebijakan kawasan perdagangan bebas yaitu kebijakan ekonomi yang mulai di terapkan di Kota batam pada April 2009 memberikan pengaruh yang begitu penting terhadap perkembangan daerah di Kota Batam. Dapat dilihat dengan mengukur adanya suatu pengaruh dengan menggunakan beberapa faktor yaitu :

\section{Hubungan Timbal Balik}

Hubungan timbal balik merupakan hubungan sebab akibat anatara apa yang mempengaruhi dan apa yang di pengaruhi dua hal inilah yang akan dihubungkan apa ada hal yang menghubungkannya. Dalam hal ini pengukuran dari faktor yang akan digunakan untuk menjawab rumusan masalah yaitu, hubungan sebab akibat antara standard fitur kebijakan kawasan perdagangan bebas dengan faktor perkembangan di suatu daerah. Adanya standard yang harus di terapkan dalam pelaksanaan kebijakan kawasan perdagangan bebas tersebut, dengan sendirinya memberikan pengaruh terhadap faktor perkembangan daerah di kota Batam. Menurut hasil questioner untuk indikator hubungan timbal balik yang di dapatkan dengan 56 sampel yaitu:

Tabel 3 Jumlah Bobot dan Presentasi Nilai

\begin{tabular}{|c|c|c|c|}
\hline \multicolumn{2}{|c|}{ Tabel Bobot Nilai } & \multicolumn{2}{|c|}{ Tabel Presentasi Nilai } \\
\hline SS & 5 & $80 \%-100 \%$ & Sangat Setuju \\
\hline S & 4 & $60 \%-79.99 \%$ & Setuju \\
\hline RR & 3 & $40 \%-59.99 \%$ & Ragu-Ragu \\
\hline TS & 2 & $20 \%-39.99 \%$ & Tidak Setuju \\
\hline STS & 1 & $0 \%-19.99 \%$ & Sangat Tidak Setuju \\
\hline
\end{tabular}

Maka Hasil Perhitungan jawaban responden sebagai berikut :

$($ Skor $=$ Hasil Jawaban X Bobot Nilai $)$ 
Tabel 4 Perhitungan Skor Jawaban Responden

\begin{tabular}{|l|c|c|c|c|c|}
\hline \multirow{2}{*}{ Keterangan } & \multicolumn{6}{|c|}{ Hasil Jawaban } \\
\cline { 2 - 7 } & SS & S & RR & TS & STS \\
\hline Pertanyaan 1 & 22 & 34 & 0 & 0 & 0 \\
\hline Pertanyaan 2 & 17 & 35 & 4 & 0 & 0 \\
\hline Pertanyaan 3 & 6 & 39 & 9 & 2 & 0 \\
\hline Pertanyaan 4 & 18 & 29 & 9 & 0 & 0 \\
\hline Pertanyaan 5 & 16 & 28 & 12 & 0 & 0 \\
\hline \multicolumn{7}{|c|}{ Skor } \\
\hline SS & S & RR & TS & STS & Total \\
\hline 110 & 136 & 0 & 0 & 0 & 246 \\
\hline 85 & 140 & 12 & 0 & 0 & 237 \\
\hline 30 & 156 & 27 & 4 & 0 & 217 \\
\hline 90 & 116 & 27 & 0 & 0 & 233 \\
\hline 80 & 112 & 36 & 0 & 0 & 228 \\
\hline
\end{tabular}

Hasil interpretasi:

1. $\mathbf{Y}=$ Skor tertinggi likert $\mathrm{x}$ jumlah responden $(5 \mathrm{X} 56=280)$

2. $\mathbf{X}=$ Skor terendah likert $\mathrm{x}$ jumlah responden $(1 \mathrm{X} 56=56)$

3. Rumus Index $\%=\underline{\text { Total Skor }}$

$$
\text { Y x } 100
$$

Maka penyelesaiannya:

Pertanyaan 1= Kategori Sangat Setuju

$$
(246 / 280 \times 100=87.8 \%)
$$

Pertanyaan 2= Kategori Sangat Setuju

$$
(237 / 280 \times 100=.84 .6 \%)
$$

Pertanyaan 3 = Kategori Setuju

$$
(217 / 280 \times 100=77.5 \%)
$$

Pertanyaan 4= Kategori Sangat Setuju

$$
(233 / 280 \times 100=83.4 \%)
$$

Pertanyaan 5= Kategori Sangat Setuju

$$
(228 / 280 \times 100=81.4 \%)
$$

Berdasarkan hasil yang didapat dengan menggunakan indikator hubungan timbal balik yang di peroleh melalui angket dengan menggunakan metode skala likert yaitu 4 dari 5 pernyataan mendapat jawaban sangat setuju dan selebihnya mendapatkan jawaban setuju. Sehingga dapat disimpulkan bahwa adanya pengaruh kebijakan kawasan perdagangan bebas terhadap perkembangan daerah di Kota Batam pada periode tahun 2010-2014. 


\section{Perubahan}

Perubahan yaitu hasil suatu masyarakat yang mencari cara memecahkan masalah yang diciptakan oleh perubahan dalam lingkungannya.Perubahan yang akan diukur dalam penelitian ini yaitu perubahan yang terjadi terhadap beberapa faktor yang berkaitan dengan faktor-faktor perkembangan daerah yaitu perubahan terhadap perkembangan sumber daya manusia, perubahan terhadap jumlah investasi, perubahan terhadap perkembangan teknologi.

\section{Investasi}

Ketersediaan modal merupakan faktor yang amat penting di dalam setiap kegiatan usaha, karena modal merupakan sumber energi baik untuk kelangsungan, pengembangan, maupun pertumbuhan usaha. Untuk itu diperlukan adanya kegiatan investasi yang dapat menjadi sumber modal bagi kegiatan pembangunan yang sedang dilaksanakan. Investasi mempunyai arti penting pula di dalam penyerapan tenaga kerja, karena dengan adanya investasi baik nasional maupun asing, akan meningkatkan kegiatan atau menghidupkan kembali sektor riil. Hal ini akan menyerap tenaga kerja sehingga dengan adanya investasi ini akan membuka lapangan kerja baru serta mengurangi penggangguran. Agar supaya harapan pemerintah ini dapat terlaksana, maka untuk investasi asing diarahkan supaya dapat memberikan lapangan kerja bagi tenaga kerja lokal, membuka lapangan kerja baru serta tidak mendorong kegiatan ekonomi yang padat modal yang dapat menyaingi kegiatan yang dapat dilakanakan secara padat karya.

Tabel 5 Jumlah Kumulatif Investasi Tahun 2010-2014 (US \$ Milyar
\begin{tabular}{|l|c|c|c|c|c|}
\hline Indikator & $\mathbf{2 0 1 0}$ & $\mathbf{2 0 1 1}$ & $\mathbf{2 0 1 2}$ & $\mathbf{2 0 1 3}$ & $\mathbf{2 0 1 4}$ \\
\hline Kumulatif Investasi Total & 14.59 & 14.92 & 15.69 & 16.47 & 17.71 \\
\hline Kumulatif Investasi Pemerintah & 2.92 & 3.00 & 3.09 & 3.37 & 3.62 \\
\hline Kumulatif Investasi Asing & 5.94 & 6.16 & 6.78 & 7.28 & 8.27 \\
\hline Kumulatif Investasi Domestik & 5.73 & 5.75 & 5.82 & 5.82 & 5.82 \\
\hline
\end{tabular}

Sumber : Kantor BP Badan Pengusaha Batam

Berdasarkan tabel di atas dapat di lihat besar jumlah investasi meningkat dari tahun ke tahun selama periode 2010-2014. Pada tahun 2010 jumlah kumulatif investasi total yaitu US\$ 14.59 Milyar, tahun 2011 US\$ 14.92 Milyar, tahun 2012US\$ 15.69 Milyar, tahun 2013US\$ 16.47 Milyar, tahun 2014US\$ 17.71 Milyar, selain itu dapat diketahui bahwa jumlah kumulatif investasi asing adalah penyumbang angka terbesar secara berturut - turut dari tahun 2010-2014. 


\section{Sumber Daya Manusia}

Sumber daya manusia merupakan salah satu faktor yang sangat penting dalam suatu perusahaan. Disamping faktor yang lain seperti modal, sumber daya manusia menjadi salah satu faktor dalam perkembangan suatu daerah. Penerapan kebijakan kawasan perdagangan bebas di kota Batam secara tidak langsung menuntut adanya kualitas sumber daya manusia yang lebih berkualitas dan unggul agar dapat mempertahankan kualitas-kualitas dan hasil produksi. Berikut jumlah sumber daya manusia yang tersedia di kota Batam periode 20101014:

Tabel 6 Jumlah Tenaga Kerja Indonesia dan Tenaga Kerja Asing Tahun 2010-2014

\begin{tabular}{|c|c|c|}
\hline Tahun & $\begin{array}{c}\text { Tenaga Kerja } \\
\text { Indonesia }\end{array}$ & $\begin{array}{c}\text { Tenaga Kerja } \\
\text { Asing }\end{array}$ \\
\hline 2010 & 288,318 & 5,108 \\
\hline 2011 & 313,544 & 5,510 \\
\hline 2012 & 330,592 & 5,970 \\
\hline 2013 & 349,649 & 5,995 \\
\hline 2014 & 341,994 & 5,702 \\
\hline
\end{tabular}

Berdasarkan tabel di atas dapat di lihat jumlah tenaga kerja mengalami peningkatan 2010-2013 sedangkan pada tahun 2014 jumlah tenaga kerja mengalami penurunan angka sebesar 7,655 orang untuk tenaga kerja Indonesia dan 293 orang untuk tenaga kerja asing. Perkembangan sumber daya manusia di Kota Batam dapat di lihat melalui tingkat keberhasilan pembangunan sumber daya manusia yang diukur menggunakan angka indeks pembangunan manusia.

Indeks pembangunan manusia merupakan indikator komposit tunggal yang digunakan untuk mengukur pencapaian pembangunan manusia yang telah dilakukan di suatu daerah. Walaupun tidak dapat mengukur semua dimensi dari pembangunan manusia, indeks ini mampu mengukur dimensi pokok pembangunan manusia yang dinilai mencerminkan status kemampuan dasar (basic capabilities) penduduk.Indikator dalam Indeks pembangunan manusia secara teknis dipandang mudah dipahami, valid, reliabel, dan parsimoni, serta terstandardisasi, sehingga mudah dibandingkan antardaerah dan antarwaktu.

Berikut perkembangan sumber daya manusia di Kota Batam yang diukur menggunakan IPM periode 2010-1014: 


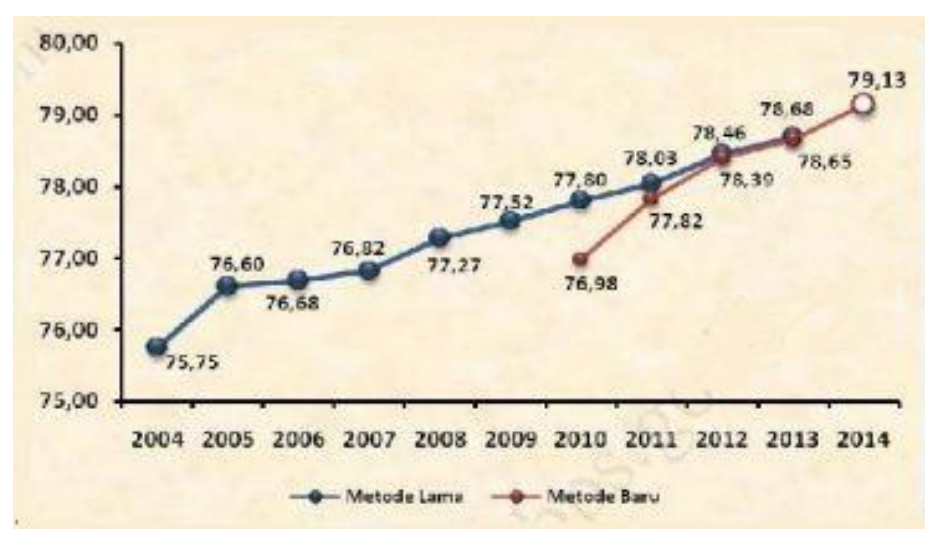

Gambar 1 Perkembangan IPM Kota Batam Tahun 2010-2014 Sumber : Kantor BP Badan Pengusaha Batam

Indeks Pembangunan Manusia bernilai 1-100 yang semakin tinggi menyatakan status pencapaian yang lebih tinggi. Untuk melihat capaian tersebut, di kelompokkan ke dalam beberapa kategori yaitu:

1. IPM $<60$ : IPM rendah

2. $60 \leq \mathrm{IPM}<70 \quad$ :IPM sedang

3. $70 \leq \mathrm{IPM}<80 \quad$ :IPM tinggi

4. $I P M \geq 80 \quad:$ IPM sangat tinggi

Berdasarkan gambar 4.1 di atas pada tahun 2010 perkembangan IPM kota Batam 76.98, tahun 2011 77.82, tahun 2012 78.39, tahun 2013 78.65, tahun 2014 79.13. Dari angka tersebut menunjukan bahwa perkembangan IPM kota Batam semakin meningkat dari tahun 2010-2014 dan angka yang di dapatkan menunjukan kategori kelompok IPM tinggi dengan batas tolak ukur $70 \leq \mathrm{IPM}<80$.

\section{Teknologi}

Kemampuan dan penguasaan teknologi merupakan kemampuan untuk menggunakan teknologi secara efektif yang dapat dicapai melalui upaya teknologis. Upaya teknologi merupakan usaha untuk menggunakan informasi teknologi yang tersedia, mengakumulasikan pengetahuan teknologi yang diperoleh untuk memilih, membaurkan, dan menyesuaikan teknologi yang ada dan atau menciptakan teknologi baru. 
Perkembangan teknologi di Kota Batam dapat di katakan meningkat dari tahun 20102014 hal tersebut dikarenakan sejak diterapkanya kebijakan kawasan perdagangan bebas membuat banyak teknologi masuk ke Kota Batam dengan cara yang beragam, mulai dari penjualan barang elektronik dari luar Negara hingga konsep alih teknologi melalui perusahaan-perusahaan asing. Penguasaan teknologi tidak hanya mengacu pada efisiensi teknis, tetapi juga meliputi kemampuan untuk menyesuaikan teknologi sehingga lebih cocok dengan kondisi dan kemampuan untuk menciptakan teknologi baru yang lebih baik.

\section{Alih Teknologi}

Merupakan salah satu cara untuk memperoleh kemampuan teknologi dengan proses memindahkan kemampuan, pengetahuan, teknologi, metode manufaktur, sampel hasil manufaktur, dan fasilitas, antara pemerintah, universitas, dan institusi lainnya yang menjamin bahwa perkembangan ilmu dan teknologi dapat diakses oleh banyak pengguna. Hal ini penting demi pengembangan lebih lanjut dan penggunaannya menjadi produk, proses, aplikasi, material, dan produk jasa baru.Konsep alih teknologi dapat dibedakan beberapa jenis yaitu Foreign Direct Invesment, Join Ventures, Turnkey Projects, Licensing Agreement.

Tabel 7 Jumlah Kumulatif UKM dan Perusahaan Asing di Kota Batam Tahun 2010 - 2014

\begin{tabular}{|c|c|c|}
\hline Tahun & $\begin{array}{c}\text { Kumulatif Usaha } \\
\text { Kecil \& Menengah }\end{array}$ & $\begin{array}{c}\text { Kumulatif } \\
\text { Perusahaan Asing }\end{array}$ \\
\hline 2010 & 9,900 & 1,247 \\
\hline 2011 & 9,900 & 1,349 \\
\hline 2012 & 10,726 & 1,443 \\
\hline 2013 & 10,726 & 1,563 \\
\hline 2014 & 10,726 & 1,699 \\
\hline
\end{tabular}

Sumber : Kantor BP Badan Pengusaha Batam

Berdasarkan tabel di atas dapat dilihat bahwa jumlah perusahaan modal asing dan uasaha kecil menengah yang ada di Kota Batam semakin meningkat jumlahnya dari tahun 2010 -2014, kenaikan angka tersebut menjelaskan bahwa semakin banyak perusahaan yang ada di Kota Batam maka semakin banyak pula sumber daya untuk berlangsungnya proses alih teknologi di Kota Batam yang mana hal tersebut mengakibatkan kemajuan teknologi di Kota Batam berkembang semakin pesat. 


\section{Informasi Dan Komunikasi}

Kategori Informasi dan Komunikasi memiliki peranan sebagai penunjang aktivitas di setiap bidang ekonomi. Dalam era globalisasi, peranan kategori ini sangat vital dan menjadi indikator kemajuan suatu bangsa, terutama jasa telekomunikasi. Kontribusi kategori ini terhadap perekonomian di Kota Batam dari tahun 2010-2014 berturut-turut sebesar 2,39\%, $2,15 \%, 2,24 \%, 2,11 \%$, dan $2,04 \%$.

Sedangkan laju pertumbuhannya menunjukkan angka yang berfluktuasi. Pada tahun 2011 laju pertumbuhan kategori ini mencapai sebesar 7,12 \% dan pada tahun 2012 mengalami percepatan pertumbuhan hingga 15,77 \% yang merupakan laju pertumbuhan tertinggi sepanjang tahun 2011-2014, sedangkan pada tahun 2013 laju pertumbuhan kategori ini mengalami akselerasi menjadi 6,49 \% dan pada tahun 2014 laju pertumbuhannya kembali menguat menjadi $8,56 \%$.

\section{Infrastruktur, Sarana Pelayanan Umum \& Khusus, Fasilitas Umum \& Sosial}

Kemajuan dalam bidang teknologi di suatu daerah juga dapat dilihat dari segi pembangunan infrastruktur, sarana pelayanan umum dan khusus serta fasilitas umum dan sosial yang ada, dalam proses pembangunan infrastruktur,sarana pelayanan umum dan khusus serta fasilitas umum dan sosial tak lepas dari kemajuan teknologi yang menjadi salah satu faktor penting dalam mengukur sejauh mana kualitas hasil dari pembangunan tersebut. Selain itu dengan adanya fasilitas-fasilitas tersebut juga menjadi salah satu acuan atau pertimbangan bagi investor untuk dapat melihat perkembangan teknologi di daerah tersebut sebelum berinvestasi di Kota Batam karena hal tersebut sangat berpengaruh dalam kelancaran proses operasional suatu perusahaan.

Menurut hasil questioner yang di dapatkan oleh peneliti untuk indicator perubahan dengan 56 samepl yaitu:

Tabel 8 Jumlah Bobot dan Presentasi Nilai

\begin{tabular}{|c|c|c|c|}
\hline \multicolumn{2}{|c|}{ Tabel Bobot Nilai } & \multicolumn{2}{c|}{ Tabel Presentasi Nilai } \\
\hline SS & 5 & $80 \%-100 \%$ & Sangat Setuju \\
\hline S & 4 & $60 \%-79.99 \%$ & Setuju \\
\hline RR & 3 & $40 \%-59.99 \%$ & Ragu-Ragu \\
\hline TS & 2 & $20 \%-39.99 \%$ & Tidak Setuju \\
\hline STS & 1 & $0 \%-19.99 \%$ & Sangat Tidak Setuju \\
\hline
\end{tabular}


Tabel 9 Perhitungan Skor Jawaban Responden

\begin{tabular}{|c|c|c|c|c|c|c|}
\hline \multirow{2}{*}{\multicolumn{2}{|c|}{ Keterangan }} & \multicolumn{5}{|c|}{ Hasil Jawaban } \\
\hline & & SS & $\mathrm{S}$ & $\mathrm{RF}$ & TS & STS \\
\hline \multicolumn{2}{|c|}{ Pertanyaan 1} & 12 & 35 & 7 & 2 & 0 \\
\hline \multicolumn{2}{|c|}{ Pertanyaan 2} & 13 & 35 & 8 & 0 & 0 \\
\hline \multicolumn{2}{|c|}{ Pertanyaan 3} & 7 & 38 & 11 & 0 & 0 \\
\hline \multicolumn{2}{|c|}{ Pertanyaan 4} & 14 & 35 & 6 & 1 & 0 \\
\hline \multicolumn{2}{|c|}{ Pertanyaan 5} & 22 & 32 & 2 & 0 & 0 \\
\hline \multicolumn{2}{|c|}{ Pertanyaan 6} & 18 & 29 & 9 & 0 & 0 \\
\hline \multicolumn{2}{|c|}{ Pertanyaan 7} & 8 & 35 & 12 & 1 & 0 \\
\hline \multicolumn{2}{|c|}{ Pertanyaan 8} & 13 & 30 & 12 & 1 & 0 \\
\hline \multicolumn{2}{|c|}{ Pertanyaan 9} & 26 & 28 & 2 & 0 & 0 \\
\hline \multicolumn{2}{|c|}{ Pertanyaan 10} & 27 & 21 & 8 & 0 & 0 \\
\hline \multicolumn{2}{|c|}{ Pertanyaan 11} & 8 & 26 & 17 & 5 & 0 \\
\hline \multicolumn{2}{|c|}{ Pertanyaan 12} & 19 & 34 & 3 & 0 & 0 \\
\hline \multicolumn{7}{|c|}{ Skor } \\
\hline SS & $\mathrm{S}$ & RR & TS & \multicolumn{2}{|c|}{ STS } & Total \\
\hline 60 & 140 & 21 & 4 & \multicolumn{2}{|c|}{0} & 225 \\
\hline 65 & 140 & 24 & 0 & \multicolumn{2}{|c|}{0} & 229 \\
\hline 35 & 152 & 33 & 0 & \multicolumn{2}{|c|}{0} & 220 \\
\hline 70 & 140 & 18 & 2 & \multicolumn{2}{|c|}{0} & 230 \\
\hline 110 & 128 & 6 & 0 & \multicolumn{2}{|c|}{0} & 244 \\
\hline 90 & 116 & 27 & 0 & \multicolumn{2}{|c|}{0} & 233 \\
\hline 40 & 140 & 36 & 2 & \multirow{2}{*}{\multicolumn{2}{|c|}{$\frac{0}{0}$}} & 218 \\
\hline 65 & 120 & 36 & 2 & & & 218 \\
\hline 130 & 112 & 6 & 0 & \multicolumn{2}{|c|}{0} & 242 \\
\hline 135 & 84 & 24 & 0 & \multicolumn{2}{|c|}{0} & 243 \\
\hline 40 & 104 & 51 & 10 & \multicolumn{2}{|c|}{0} & 205 \\
\hline 95 & 136 & 9 & 0 & \multicolumn{2}{|c|}{0} & 240 \\
\hline
\end{tabular}

Hasil interpretasi :

1. $\mathbf{Y}=$ Skor tertinggi likert $\mathrm{x}$ jumlah responden $(5 \mathrm{X} 56=280)$

2. $\mathbf{X}=$ Skor terendah likert $\mathrm{x}$ jumlah responden $(1 \mathrm{X} 56=56)$

3. Rumus Index $\%=$ Total Skor $/ \mathrm{Y} \times 100$

Maka penyelesaiannya

(Total Skor / Y x 100)

Pertanyaan 1=Kategori Sangat Setuju

$$
(225 / 280 \times 100=80.3 \%)
$$

Pertanyaan 2= Kategori Sangat Setuju

$$
(229 / 280 \text { X } 100=81.7 \%)
$$

Pertanyaan 3= Kategori Setuju

$$
(220 / 280 \text { X } 100=78.5 \%)
$$

Pertanyaan 4= Kategori Sangat Setuju 


$$
(230 / 280 \times 100=82.1 \%)
$$

Pertanyaan 5= Kategori Sangat Setuju

$$
(244 / 280 \times 100=87.1 \%)
$$

Pertanyaan 6= Kategori Sangat Setuju

$$
(233 / 280 \times 100=83.2 \%)
$$

Pertanyaan 7= Kategori Setuju

$$
(218 / 280 \times 100=77.8 \%)
$$

Pertanyaan 8= Kategori Setuju

$$
(218 / 280 \times 100=77.8 \%)
$$

Pertanyaan 9= Kategori Sangat Setuju

$$
(242 / 280 \times 100=86.4 \%)
$$

Pertanyaan10=Kategori Sangat Setuju

$$
(243 / 280 \times 100=86.7 \%)
$$

Pertanyaan $11=$ Kategori Setuju

$(205 / 280 \times 100=73.2 \%)$

Pertanyaan12=Kategori Sangat Setuju

$$
(240 / 280 \times 100=85.7 \%)
$$

Berdasarkan hasil yang diperoleh oleh peniliti dalam menggunakan indikator hubungan perubahan yang di peroleh melalui angket dengan menggunakan metode skala likert yaitu 8 dari 12 pernyataan mendapat jawaban sangat setuju dan selebihnya mendapatkan jawaban setuju oleh karna itu peneliti berasumsi terdapat pengaruh dalam penerapan kebijakan kawasan perdagangan bebas terhadap perkembangan daerah di kota Batam.

\section{KESIMPULAN}

Melihat dari indikator untuk melihat adanya suatu pengaruh, adanya suatu hubungan timbal balik yang terjadi anatara fitur-fitur kebijakan kawasan perdagangan bebas terhadap faktor-faktor perkembangan daerah di kota Batam dan perubahan yang terjadi dari tahun 2010-2014 terhadap jumlah nilai investasi, sumber daya manusia dan perkembangan teknologi, hal tersebut menjadi point penting dalam melihat adanya suatu pengaruh dan keuntungan yang didapat oleh kota Batam dalam penerapan kebijakan tersebut. Maka dari itu dapat disimpulkan bahwa kebijakan kawasan perdagangan bebas yang di terapkan di kota Batam memberikan pengaruh terhadap perkembangan daerah di kota Batam pada periode tahun 2010-2014. 


\section{DAFTAR PUSTAKA}

Azwar, Saifuddin. (1995). Teori dan Pengukurannya. Yogyakarta: Pustaka Pelajar.

Creswell, John W. and Vicki L. Plano Clark. (2008). Designing and conducting mixed methods research. London: Sage Publications

Fairholm, Gilbert W. (2009). Tactics in Organizational Leadership, 2nd Edition. Santa Barbara.

Richardson, Harry W. (1973). Regional Economic Growth. London: University of Illinois Press.

Krejcie, Robert V. (1970) Determining Sample Size For Research Activities. University Of Minnesota, Duluth Daryle W. Morgan Texas A. \& M. University Educational And Psychological Measurement. Texas

United Nations and Korea Maritime Institute. (2005) Free Trade Zone and Port Hinterland Development. New York : United Nation Publication

Winarno, Surakhmad. (1985). Pengantar Penelitian Ilmiah. Bandung: Tarsito. 